\title{
GEOCHEMICAL ANALYSIS AND PREPARATION THE WELL ABANDONMENT PROJECTS ON THE POLANA OSTRE FIELD**
}

\section{BACKGROUND}

Polana is one of the biggest villages in the region of Bieszczady. It is located in south-east Poland in the Subcarpathian Voivodeship. This region is well-known as an abundant in hydrocarbons. Exploration and production have been continued since the $19^{\text {th }}$ century and this region is perceived as one of the places where the proper oil industry had begun [1]. Polana was founded in the half of the $15^{\text {th }}$ century and was the only one located in the middle of Bieszczady, laying under the massive of Ostre. Many local stories from that period have mentioned about surface leakages of oily substance with a characteristic smell. After years of analysis (Filip Walter, Abraham Gesesner) the refining process was discovered and a potential application of oil was proven. The Polish scientist, Ignacy Łukasiewicz managed to apply a liquid oil fraction - kerosene as a fuel for a lamp, invented by him. This event dated on 1853 was a breakthrough and it increased interest in oil as an energy source. It was also the historical beginning of the petroleum industry in Poland.

\section{HISTORY OF POLANA OIL MINE}

The first documented discovery in Polana region was made by the geologist - Henryk Walter. Based on surface observations and geological formation, Walter contributed in decision making process regarding well placement. Thanks to that, in 1870 around Polana, 38 hand-made oil wells have being produced and started an industrial activity of Polana oil mine [2]. The facility periodically has changed ownership but the main shareholders were Hans Bullow and Fryderyk Isherwood. The personal relationship between these two gentlemen was an initial problem that affected the whole facility in terms of funding and development.

* AGH University of Science and Technology, Student Scientific Association GEOWIERT, Krakow, Poland

** The project was sponsored by AGH Rectors Grant and GEOS Foundation 
Isherwood intended to separate part of area but according to Polish Mining Law from 1854, an oil production license could be awarded only if the produced hydrocarbons would not be used directly for lighting purposes. This record was evaded by acquiring a contract with Gartenbergs \& Company - receiver that was responsible for wax production. As a consequence Polana was divided into two parts and this fact caused a long term conflict. Additionally, unsuccessful exploration wells were the reasons for a temporary suspension of activities until 1883 when during drilling the sudden kick of oil occurred. Approximately $1000 \mathrm{bbl}\left(158.96 \mathrm{~m}^{3}\right)$ were lost but this accident caused a boom for oil and Polana again became a centre of attention for international investors such as the Anglo-Galician Comp., Bergheim, Mac Garvey, the Gartenberg Brothers and London Petroleum [2, 3].

Polana was also a place where new technologies were tested. One of these was a rapid drilling system invented by Albert Fauck. It assumed a conversion of the rotary motion of the drive shaft into the up-and-down motion of the drill column took place using chains or cables through an eccentrically-arranged disk and no longer through a walking beam. Without the heavy weight of the walking beam, and with a small stroke of just 50-100 m and very accurate guidance of the chain, it was possible to drill up to $60 \mathrm{~m}$ each day to depths of up to two kilometers in the next generations [4]. Another new technology was related to placing the explosives on the bottom of the wellbore in order to increase production rates. $100 \mathrm{~kg}$ of trotyl was used and fired under the supervision of Thurmann from a Nobel company. The intensification process caused the production rate increment from $3 \mathrm{bbl}$ to $100 \mathrm{bbl}$ $\left(0.477-15.896 \mathrm{~m}^{3}\right)$ per day [3].

According to sources $[2,3]$ the companies applied an unbalanced draining strategy and resources were produced as fast as possible in order to achieve quick profits. Also, inexperienced staff caused several problems with water inflow to the reservoir. Unprofessionally performed abandonment work that covered the removal of the casing caused a rapid inflow from water bearing formations to several wells. Another issue was related to low margins in the following years.

Due to an increased import of cheap oil from the United States, the oil mines without a permanent and efficient transportation system were losing their profitability. For this reason in 1913, after a few years of suspension, a 2 in $(5.08 \mathrm{~cm})$ pipeline was installed to connect the facility with the railway station in Ustrzyki. Its length was $21.6 \mathrm{~km}$ and in that time it was a significant investment [2].

Notable problems with production occurred during the $1^{\text {st }}$ and the $2^{\text {nd }}$ World War. The area of Polana was controlled by Austria, Ukraine and finally Poland in 1922. Thanks to the engagement of local people, the surface facility was not destroyed. The one who managed the Polana in that time was Ludwik Stadtmuller.

During the interwar period the facility was controlled by his descendants. In 1937 it was decided to redevelop the field and drill new wells but the predicted prosperity was suddenly stopped in 1939.

During the $2^{\text {nd }}$ World War fuel shortages and an aggressive production scheme was chosen by Germans who occupied this territory, to supply military vehicles. Finally the oil mine was burnt by Polish partisans and overtaken by USSR in 1944. Poland reclaimed this area in 1951 [2]. After stocktaking, it turned out that the field was unqualified for further development. In this devastated state, the area of the former oil production plant survived till the present days. 


\section{REGULATIONS}

In accordance to the present Polish Mining Law Regulations, Polana field is a source of serious environmental pollution. In the time when the reservoir was abandoned, it was not sealed properly. In present days Polana is under the control of the Polish Oil and Gas Company Sanok. Polish Law [5] states that during every mining activity, an abandonment fund must be created. It is purpose-opened bank account that gathers funds before and during production stage, in order to cover the costs of proper sealing and rehabilitation of the area. This requirement did not exist during the production time. Nowadays, it is also difficult to point the subject that should be responsible for the field.

In recent years, Stadtmullers' descendants were trying to retain the control over Polana area and even redevelopment plans were discussed. However, in Poland all the mineral resources belong and are managed by State Treasury so this individual initiative cannot be successful.

The local community was trying to create a museum similar to this in Bóbrka. Despite the undoubted Polanas' contribution into the petroleum industry, it did not happen.

\section{PRESENT STATE OF FACILITY AND PROJECT ASSUMPTIONS}

The serious issue that was visible at a glance was the presence of numerous surface leakages of oil and many wells that were not properly abandoned. It caused notable environmental pollution. The reservoir was periodically active and some gas exhausts could be observed. Based on interviews with local people, sometimes even small local earthquakes and explosions could be experienced as a result of the reservoir's activity. According to research, no data regarding the wells placement was available so it was decided to recognize the area of Polana field and describe it. Also as a result of the project, two future scenarios were considered but finally instead of redeveloping, the proper well abandonment proposal was made. These results are going to be discussed in the further part of this article. The main motivations for this project were the intention to get familiar with a place that had started the Polish petroleum industry, check how its present state refers to regulations and propose some solutions based on field research and communication with local people and industry.

\section{RESEARCH METHODOLOGY}

The project works were designed to obtain the specific data required in further analysis. Some of them were conducted in-situ and in laboratories of AGH UST.

Fieldworks consisted of the area recognizing, boreholes identifying, geographic coordinates determining and soil gas samples taking. They took place during two expeditions on Polana Ostre oil field.

In May 2013 the first reconnaissance was conducted. 28 boreholes were identified on the Polana field. For all found wells, GPS coordinates were determined, supported by additional photographic documentation. Boreholes coordinates were mapped. All of the actions were taken in order to adjust the measuring points grid and reference to the maps. 
The second stage of the fieldworks was focused on the acquisition of the surface geochemical data. Samples were taken with a probe patented by Dzieniewicz and Sechman [6]. At first, the probe was inserted to depth 1.00-1.25 m. Then, soil gas was collected with a purpose-made syringe. Afterwards, soil gas was pushed into a gas-tight container filled with concentrated sodium chloride. Gas, while being injected to the vessel, caused sodium chloride to flow outside via needle.

Sampling locations were determined by the principle of circumference of a circle with a radius of $1.5 \mathrm{~m}$ and the center was located over the wellbore. On the circumference, the three samples were taken in equal distance. The fourth point was located in the center, in direct adjacent of the wellbore. In total, 86 samples were taken using this method. In certain cases, the gas samples could be contaminated by liquid hydrocarbons deposited in the soil. Then, each sample was analyzed with the device using a gas chromatography with a flame ionization detector. As a result, the concentrations of methane and the sum of light homologues (ethane, propane, butane and pentane) were determined.

\section{RESULTS AND ANALYSIS OF RESEARCH}

In order to analyze the concentrations of methane and higher alkanes with a reference to the location the following graphs were drafted (Fig. 1-3).

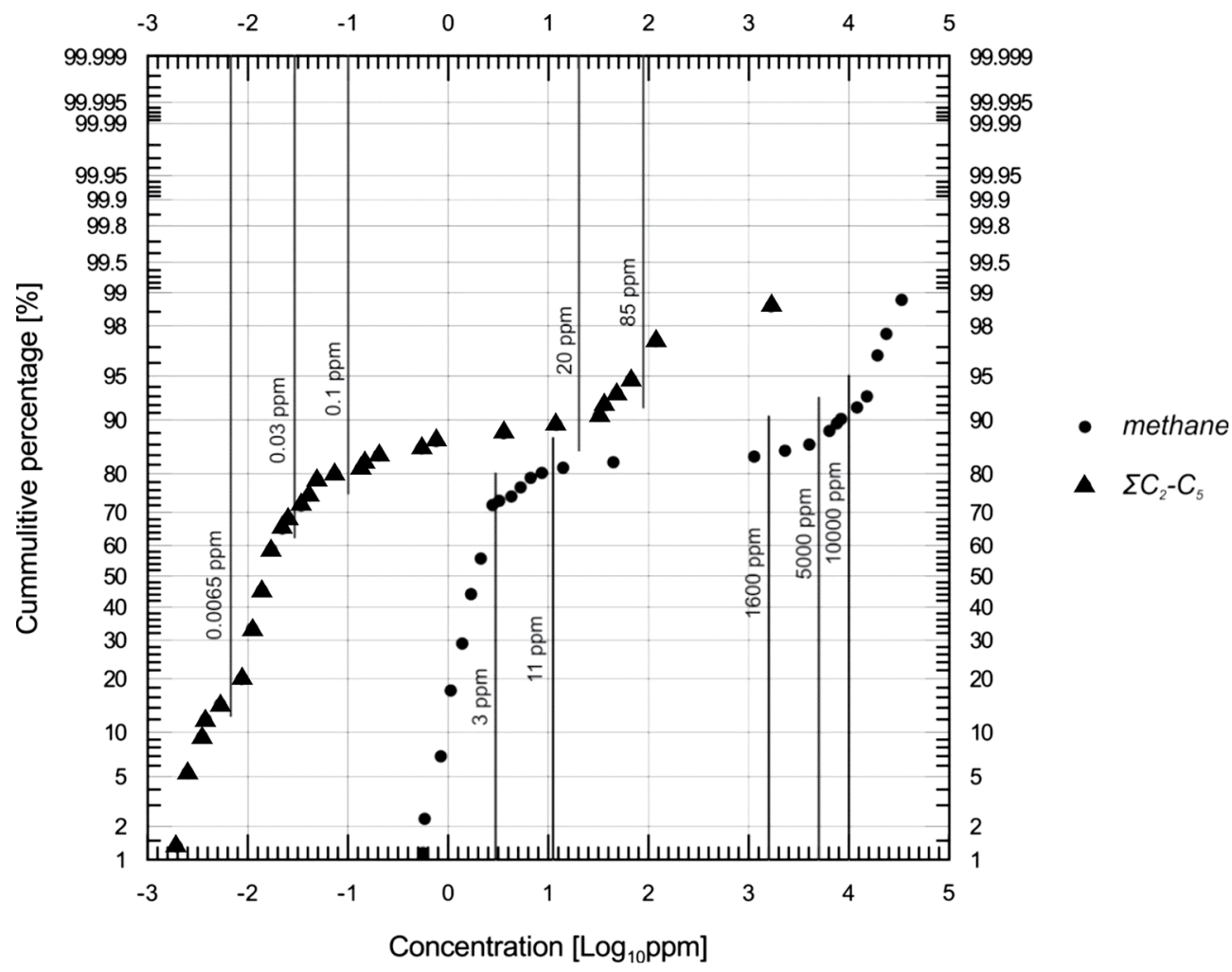

Fig. 1. Cumulative percentage vs. concentration of methane and sum of higher alkanes [7] 
Figure 1 presents the cumulative percentage participation depending on the logarithmic concentration of hydrocarbons. Concentration of methane in more than the $20 \%$ of samples is greater or equal $3 \mathrm{ppm}$. Concentration of methane crosses $10,000 \mathrm{ppm}$ in $5 \%$ of the samples. Similarly, in case of the sum of $\mathrm{C}_{2}-\mathrm{C}_{5}$ in almost $10 \%$ of samples concentration exceeded 85 $\mathrm{ppm}$. A similar distribution of results for methane and homologues, presented on Figure 1, can confirm the common source of their origin.

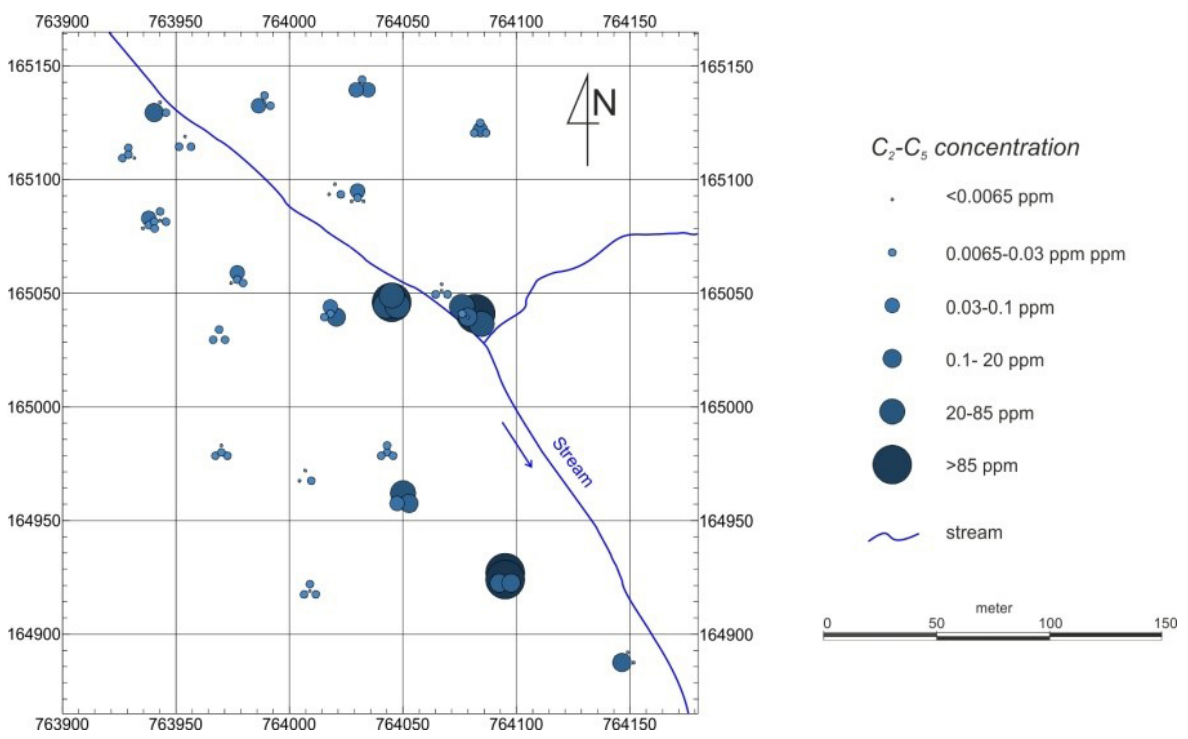

Fig. 2. Map of concentration sum of higher alkenes on Polana field [7]
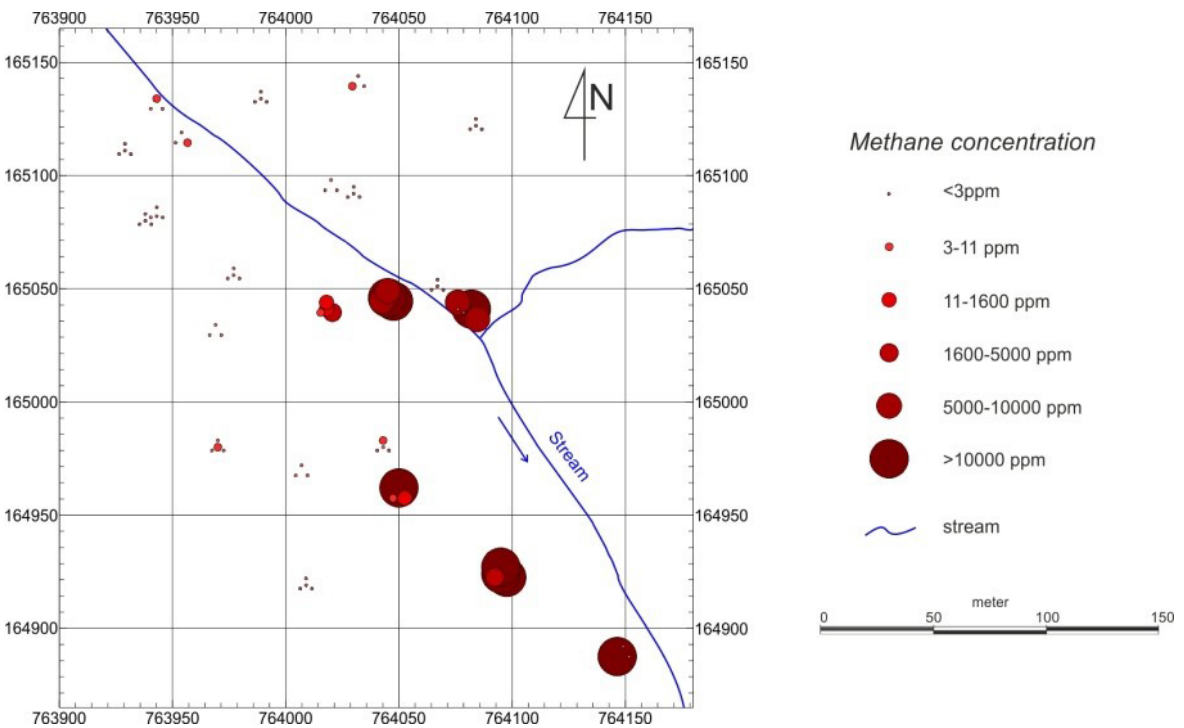

Fig. 3. Map of concentration methane on Polana field [7] 
Based on the results, chromatography maps were created (Fig. 4). Isolines show logarithmic concentration of hydrocarbons. Significant rating useful in the evaluation of the hydrocarbon source is ratio $\mathrm{C}_{1} / \mathrm{C}_{2}-\mathrm{C}_{5}$ [8]. In this case logarithmic ratio $\mathrm{C}_{1} / \mathrm{C}_{2}-\mathrm{C}_{5}$ has reached the relatively high value (Fig. $4 \mathrm{a}$ ). The result may have been affected by a rapid penetration of formations by the hydrocarbons in the direction of the surface or shallow location of the source. For example it may be caused by a leakage in place where the sample was gathered.

During the inspection of the Polana field the assumption that wells were not properly abandoned was made [9]. A surface geochemical survey showed the amount of pollution produced by the oil leakages.

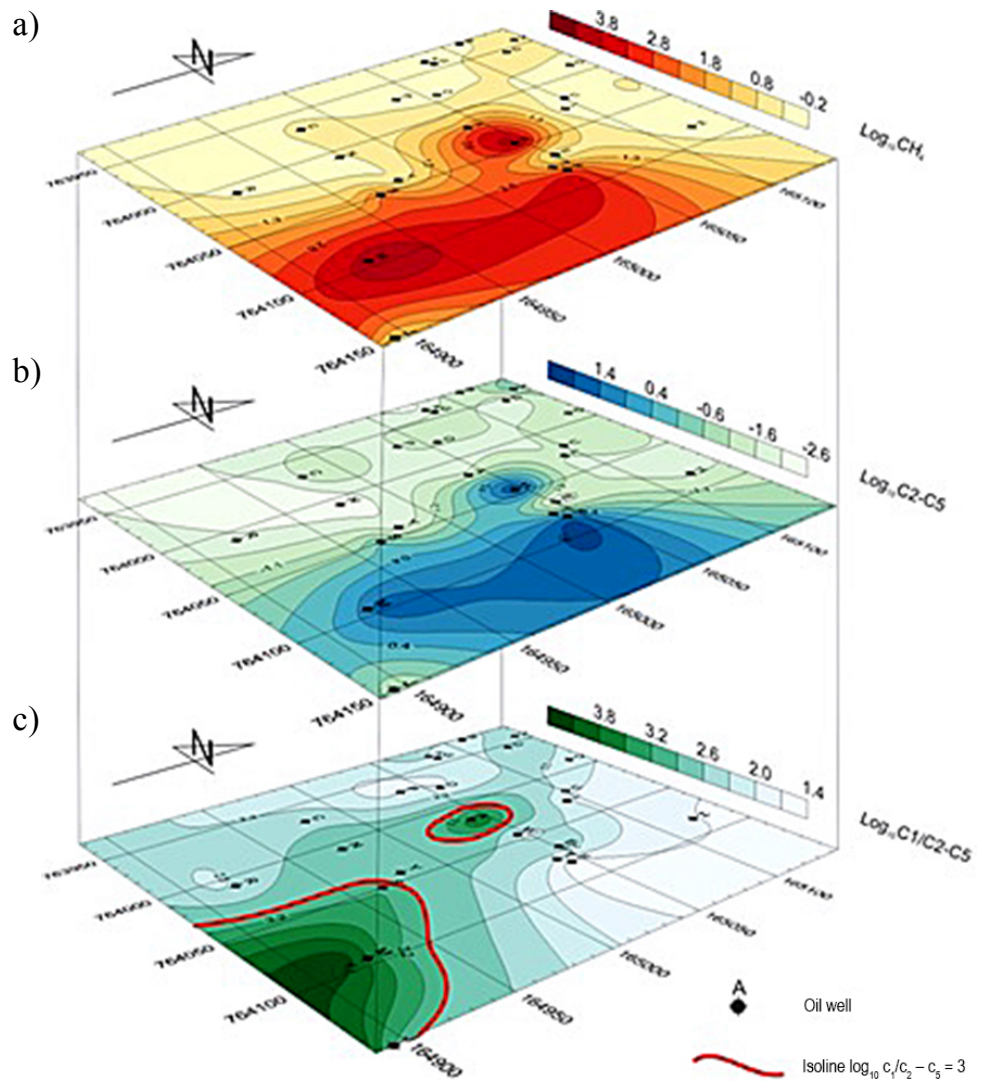

Fig. 4. Maps of logarithmic concentration of: a) methane; b) sum of higher alkanes (ethane, propane, butane, pentane); c) ratio $\mathrm{C}_{1} / \mathrm{C}_{2}-\mathrm{C}_{5}[7]$

\section{PROPOSED SCENARIO}

Geochemical results clearly show that it is necessary to perform the procedure of well abandonment. This procedure aims at eliminating the influence of reservoir on the surface conditions and securing those parts of the reservoir, which are not used. Nevertheless, there are other reasons for conducting well abandonment such as providing a tight seal between the 
aquifers and the reservoir, securing of adjacent reservoirs and ensuring concrete protection of the environment consistent with the Polish law. Each reservoir requires an individual approach. Before treatment, it is essential to analyze a number of elements, from whom the most important are general history, methods, possible complications that could occur during drilling, well construction, geological conditions and the history of exploitation of the reservoir.

In our case all wells must be permanently abandoned because they acted as a source or channel of contamination. In order to perform well abandonment several operations must be accomplished. Firstly this includes the removal of all the obstructions and casing in the well as much as it is possible. Finally, operations end when the entire well is filled up to the land surface with cement grout, bentonite grout and concrete grout. In our case those operations were very complicated due to some wells being hand-drilled without casing.

So as to create a project of well abandonment, the Ludwik borehole was selected. This borehole is characterized by the highest conditions of the casing among all the other wells located on the Polana field. Such a selection facilitated the way of presenting the treatment.

In Figure 5 we can see three different types of well casing. They include:

- 12 in $(0.30 \mathrm{~m})$ conductor casing installed up to $10 \mathrm{~m}$ and cemented to the surface;

- 10 in $(0.25 \mathrm{~m})$ surface casing installed through the 12 in $(0.30 \mathrm{~m})$ casing and continuing up to $360 \mathrm{~m}$; this casing is cemented to the surface to isolate and protect near-surface groundwater but nowadays it does not work what is proved in geochemical analysis;

- 7 in $(0.18 \mathrm{~m})$ production casing installed through the 10 in $(0.25 \mathrm{~m})$ and continuing to $500 \mathrm{~m}$.

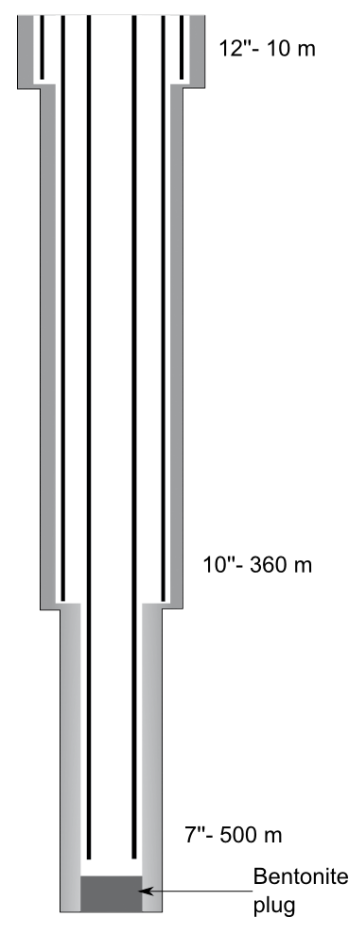

Fig. 5. Well casing 
Before the liquidation procedure it is necessary to properly prepare the site for the entry of heavy equipment. Polana is located in the Bieszczady Mountains which causes an additional problem with availability.

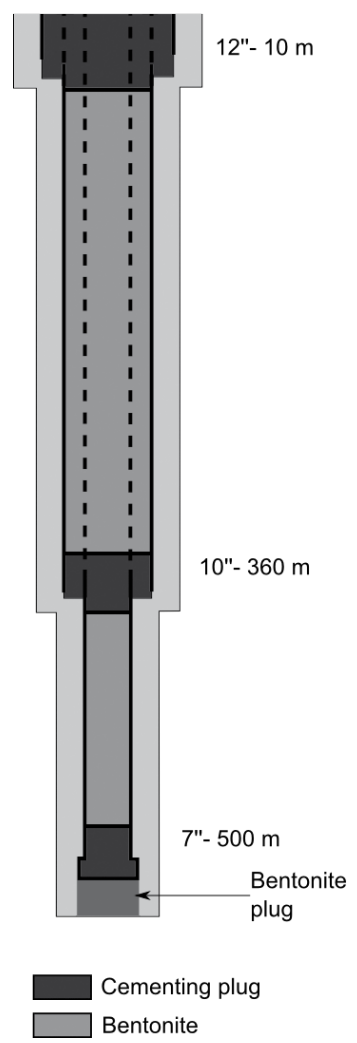

Fig. 6. Final Plug and Abandonment

Implementing the procedure on the example of the well Ludwik consists of the several steps (Fig. 6):

1. Checking the condition of the well casing.

2. Removal or drill well bottom cementing plug.

3. Creating a new well bottom cementing plug.

4. Conducting a hydrostatic pressure test.

5. Filling the interval between $470.0-370.0 \mathrm{~m}$ with bentonite grout.

6. Cutting off and removing 7 in $(0.18 \mathrm{~m})$ casing in $350 \mathrm{~m}$ depth, if it is not possible, repeating every 30 meters.

7. Creating cementing plug in the interval $370.0-320.0 \mathrm{~m}$, then conducting a hydrostatic pressure test.

8. Filling the interval between $320.0-20.0 \mathrm{~m}$ with bentonite grout.

9. Cutting off and removing 10 in $(0.254 \mathrm{~m})$ casing in $8 \mathrm{~m}$ depth, if it is not possible repeating higher. 
10. Making cementing plug in the interval between $20.0-0.0 \mathrm{~m}$.

11. Forming permanent marking of the abandoned well by a cemented plate with size of $0.6 \mathrm{~m} \times 0.6 \mathrm{~m} \times 0.2 \mathrm{~m}$ including also cemented pipe with number and name of the well.

The procedure mentioned above is an example of how to proceed with all wells.

\section{CONCLUSIONS}

1. This publication aims at drawing the attention to the problem of many Polish wells being not correctly abandoned. Those wells become a growing problem, especially when they are located in sensitive environment. Large number of leaks of gas and oil are placed in the Carpathians.

2. Underground and surface water is exposed to the risk of being contaminated by hydrocarbons. Another threat is a soil pollution that may appear. Surface geochemical surveys were evidence that such a contamination exists. They have indicated high concentration of hydrocarbons under the ground in the soil. Increased risk of fire appearance was the other aspect of those surveys.

3. The initial idea pursued by the local community in Polana was to set up a museum. It supposed to be a mean to protect the area and use abandoned wells as exhibits. The museum would have been reminder of the role which the oil industry played in economic history. Due to the high costs of borehole reconstruction, the idea was ruled out. Also redevelopment of the area infrastructure would be very expensive and inefficient. Access to the field, administrative buildings, water connection or just roads would have to be built.

4. It has turned out that re-liquidation would be a cheaper solution. That is why the decision to present the abandonment project on the example of the Ludwik borehole was made.

5. Authors also wanted to highlight that in this part of Poland oil industry were identified.

\section{ACKNOWLEDGEMENTS}

The project was a great experience. The team had an opportunity to work with a real data, on the field and contribute to a project that provides a practical outcomes. It was a perfect example of research work where numerous important sources were missing. Therefore, an extra effort was put to reflect the history of the field and understand the processes that had happened. It is another personal profit

The authors would like to express gratitude for everyone who added an input to this project, especially Scientific Student Groups KIWON and GEOWIERT, GEOS Foundation and AGH UST Rector.

\section{REFERENCES}

[1] Schatzker V., Erdheim C., Sharon A.: Petroleum in Galicia-Drohobycz Administrative District. [on-line:] http://kehilalinks.jewishgen.org/drohobycz/history/petroleum.asp [access: March 01, 2014]. 
[2] Augustyn M.: Historia kopalni ropy naftowej Polana-Ostre. Bieszczad, nr 8, 2001, pp. 84-105.

[3] Jastrzębski F.: Fragmenty pamiętnika starego nafciarza. Bieszczad, nr 8, 2001, pp. 163-172.

[4] Schmidt B.: Model of a System Rapid deep-well drilling installation, Part of the Technisches Museum Wien Exposition. 2014. [on-line:] http://www.technischesmuseum.at/ object/modell-einer-tiefbohranlage-system-rapid [access: March 01, 2014].

[5] Ustawa z dnia 9 czerwca 2011 r. Prawo geologiczne i górnicze. Dz.U. 2011 nr 163, poz. 981.

[6] Dzieniewicz M., Sechman H.: Zestaw do ręcznego pobierania próbek gazowych z warstw przypowierzchniowych. Patent nr PL 184080 B1, Pat. RP, 2002.

[7] Grywalska I., Piotrowska N., Talar D.: Badania i analiza próbek gazu glebowego pod kątem zawartości węglowodorów oraz wykonanie projektu rekonstrukcji i likwidacji otworów wiertniczych na złożu Polana. XVIII Seminarium Studenckiego Ruchu Naukowego, Kąśna Dolna-Bartkowa, 2013.

[8] Sechman H., Dzieniewicz M.: Analiza wyników powierzchniowych badań geochemicznych $w$ transgranicznej strefie Karpat polskich i ukraińskich. Geologia, t. 35, z. 4/1, 2009, pp. 109-127.

[9] Dzieniewicz M.: Badanie składu gazów glebowych-przykłady zastosowań w prospekcji naftowej i ochronie środowiska. Geologia, t. 35, z. 2/1, 2009, pp. 129-137. 